\title{
УДОСКОНАЛЕННЯ ДЕРЖАВНОГО РЕГУЛЮВАННЯ ТА КООРДИНАЦІЯ РОЗВИТКУ МОРЕГОСПОДАРСЬКОГО КОМПЛЕКСУ УКРАЇНИ
}

У дослідженні проведено аналіз теоретичних засад удосконалення державного регулювання та координації розвитку морегосподарського комплексу України в контексті сучасного інституційного оточення та реалізації морського потенціалу України. Розкрито сутність дефініції «морегосподарський комплекс», який $\epsilon$ міжгалузевим складним, багатопрофільним, иілісним акватериторіальним, функціонально-виробничим ци економіко-екологічним формуванням, щзо включає в себе компоненти наукової сфери, рекреаційний видобуток морських ресурсів, машинобудування, морський транспорт, рибне господарство та видобуток морських ресурсів. Визначено негативні тенденції розвитку морегосподарського комплексу на сучасному етапі. Зазначено, щсо помічається низький рівень інноваційної діяльності, обмеженість здійснення науково-дослідних та дослідно-конструкторських робіт у розбудові морської галузі, посилення проблем у соиіальній сфері діяльності підприємств морської індустрії (забезпечення робочими місиями, достатнього рівня оплати прачі, дієва система стимулювання пращівників морської галузі. Наголошено, щзо гарантією успішного функціонування морегосподарського комплексу в довгостроковій перспективі є його здатність адаптуватися відповідно до мінливих ринкових умов. Цього можна досягти иляхом запровадження передових інноваційних технологій, модернізації основних фондів, технічного переоснащення та формування нової комплексної моделі управління. Виходячи з иього, запропоновано напрямки вдосконалення державного регулювання розвитку морегосподарського комплексу Украӥни і доведено, щзо прискорення інтеграції вітчизняного морегосподарського комплексу до європейської економічної системи, підвищення його конкурентоспроможності та здатності задовольняти потреби національної економіки та населення передбачає здійснення техніко-технологічного оновлення суднобудівного виробництва, модернізацію наявної інфраструктури морських і річкових портів, запровадження мультимодальних транспортних технологій та інфраструктурних комплексів

Ключові слова: державне управління, координація, морегосподарський комплекс, морський порт, морська політика.

И.П. ЛОПУШИНСКИЙ

Херсонский национальный технический университет ORCID: 0000-0002-7460-7476

A.C. АРTEMЬEB

Херсонский национальный технический университет ORCID: 0000-0002-4541-9353

\section{СОВЕРШЕНСТВОВАНИЕ ГОСУДАРСТВЕННОГО РЕГУЛИРОВАНИЯ И КООРДИНАЦИЯ РАЗВИТИЯ МОРЕХОЗЯЙСТВЕННОГО КОМПЛЕКСА УКРАИНЫ}

В статье проведен анализ теоретических основ совериенствования государственного регулирования и координации развития морехозяйственного комплекса Украины в контексте современного институционального окружения и реализации морского потенциала Украины. Раскрыта сущзность дефиниции «морехозяйственный комплекс», который является межотраслевым сложным, многопрофильным, иелостным акватериториальним, функционально-производственным и экономикоэкологическим формированием, включающий в себя компоненты научной сферы, рекреационную добычу морских ресурсов, машиностроения, морской транспорт, рыбное хозяйство и добычу морских ресурсов. Определень негативные тенденции развития морехозяйственного комплекса на современном этапе. Отмечено, что наблюдается низкий уровень инновачионной деятельности, ограниченность осуществления научно-исследовательских и опытно-конструкторских работ в развитии морской отрасли, усиления проблем в социальной сфере деятельности предприятий морской индустрии (обеспечение рабочими местами, достаточного уровня оплаты труда, действенная система стимулирования работников морской отрасли. Определено, что гарантией успешного функиионирования морехозяйственного комплекса в долгосрочной перспективе является его 
способность адаптироваться в соответствии с меняющимися рыночными условиями. этого можно достичь путем внедрения передовых инновационных технологий, модернизации основных фондов, технического переоснащения и формирования новой комплексной модели управления. Исходя из этого, предложены направления совершенствования государственного регулирования развития морехозяйственного комплекса Украины и доказано, что для повышения конкурентоспособности отечественного морехозяйственного комплекса и способности удовлетворять потребности национальной экономики и населения необходимо осуществить технико-технологическое обновление судостроительного производства и соответствующую модернизацию существующей инфраструктурь морских и речных портов, внедрение в практику мультимодальных транспортных технологий $u$ инфраструктурных комплексов.

Ключевые слова: государственное управление, координация, морехозяйственного комплекса, морской порт, морская политика

I.P. LOPUSHYNSKYI Kherson National Technical University ORCID: 0000-0002-7460-7476

A.S. ARTEMYEV

Kherson National Technical University ORCID: 0000-0002-4541-9353

\section{IMPROVING STATE REGULATION AND COORDINATION OF THE DEVELOPMENT OF THE MARITIME COMPLEX OF UKRAINE}

The article analyzes the theoretical foundations of improving state regulation and coordination of the development of the maritime complex of Ukraine in the context of the modern institutional environment and the implementation of the maritime potential of Ukraine. The essence of the definition of the "maritime complex" is revealed, which is an intersectoral complex, multidisciplinary, holistic aquaterial, functional-production and economic-ecological formation, which includes components of the scientific sphere, recreational mining of marine resources, mechanical engineering, sea transport, fisheries and the extraction of marine resources. The negative trends in the development of the marine economic complex at the present stage are determined. It is noted that there is a low level of innovation, limited implementation of research and development work in the development of the maritime industry, increasing problems in the social sphere of the activities of the maritime industry (provision of jobs, a sufficient level of remuneration, an effective system of incentives for workers in the maritime industry. It has been determined that the guarantee of the successful functioning of the marine economic complex in the long term is its ability to adapt in accordance with changing market conditions. This can be achieved by introducing advanced innovative technologies, modernizing fixed assets, technical reequipment and forming a new integrated management model. State regulation of the development of the maritime complex of Ukraine and it is proved that in order to increase the competitiveness of the maritime complex and joint ventures especially to meet the needs of the national economy and the population, it is necessary to carry out a technical and technological renovation of shipbuilding production and a corresponding modernization of the existing infrastructure of sea and river ports, the introduction of multimodal transport technologies and infrastructure complexes into practice.

Keywords: public administration, coordination, maritime complex, seaport, maritime policy.

\section{Постановка проблеми}

У розвинених морських державах нині відбувається стрімке формування відтворювального осердя морегосподарського сектору економіки, заснованого на новітній технологічній базі. Такі зміни вивели на якісно новий рівень багато питань, пов'язаних як з концептуальним укомплектуванням, так і 3 практичним простором розвитку морегосподарського комплексу України. Об'єктивні закономірності переходу на інноваційну траєкторію стійкого зростання морського сполучення, відсутність у морегосподарському комплексі елементів досягнення індустріальної економіки на основі знань, та іiі формалізованого залучення - національних інноваційних систем - вимагають використання принципово нових підходів до державного регулювання та координації розвитку морегосподарського комплексу, повним обсягом його інтегрального характеру. При цьому найбільшого ефекту й результатів можна досягти за рахунок саме комплексного розвитку.

Такий підхід передбачає вироблення єдиної, цілісної, скоординованої і послідовної державної політики, націленої на підвищення результативності функціонування морегосподарського комплексу, його збалансованого просторового розвитку, комплексного вдосконалення та управління ним в цілому. Крім того, державне регулювання функціонування морегосподарського комплексу має сприяти його переходу на траєкторію сталого розвитку в інтересах не тільки нинішнього, а й майбутніх поколінь, що передбачає забезпечення конкурентоспроможності вітчизняного морегосподарського комплексу, товарів і послуг морського походження і призначення з опорою на інноваційний розвиток. 
Аналіз останніх досліджень і публікацій

Теоретичні та практичні аспекти окремих питань державного регулювання розвитку морегосподарського комплексу розглядали такі науковці як: М. Волосюк, О. Гайду, С. Горбаченко, Л. Гришина, В. Смельянов, В. Котлубай, І. Лопушинський, К. Трунін, В. Філіппова та ін.

Водночас наукові розробки в галузі державного управління розвитком морегосподарського комплексу не охоплюють усього спектра проблем. Потребують поглиблення теоретичні та практичні засади вдосконалення державного управління розвитком морегосподарського комплексу в частині усвідомлення їх сутності та напрямків модернізації.

\section{Формулювання мети дослідження}

Виходячи із вищесказаного, метою статті $є$ наукове обгрунтування теоретичних засад щодо вдосконалення державного регулювання та координації розвитку морегосподарського комплексу України в контексті сучасного інституційного оточення та реалізації морського потенціалу України.

\section{Викладення основного матеріалу дослідження}

На сьогодні очевидним є те, що політика розвитку морегосподарської діяльності є частиною державної морської політики і являє собою сукупність урегульованих дій за різноманітними напрямками морегосподарської діяльності, що реалізується в грошовій, бюджетній, податковій, інвестиційній, а також в сфері зайнятості, та спрямовані на реалізацію рішень для досягнення ефективного розвитку морегосподарської діяльності. Основною галузевою ланкою тут постає морегосподарський комплекс.

У Морській доктрині України надається досить лаконічне визначення морегосподарського комплексу як територіального поєднання об'єктів морської індустрії [1]. Воно не розкриває сутності морегосподарського комплексу ні у функціональному, ні в територіальному, ні в галузевому аспектах, проте пов'язує сутність та структуру морегосподарського комплексу з терміном «морська індустрія». Останній також фігурує в Морській доктрині та визначається як сектор економіки, що включає суб'єкти господарювання у сферах торговельного мореплавства, морського транспорту, суднобудування, судноремонту, використання ресурсів моря, які не належать до водних біоресурсів, рибного господарства.

Учені також по-різному визначають сутність дефініції «морегосподарський комплекс». Так, С. Горбачевський та Е. Каражія визначають, що морегосподарський комплекс як сукупність підприємств та галузей, діяльність яких перебуває в гармонійному взаємозв'язку в процесі використання морських ресурсів у межах приморських територій [2, с. 35].

В. Ковалевський зазначає, що морегосподарський комплекс є складною багатокомпонентною керованою системою, цільовими функціями якої $\epsilon$ забезпечення господарства країн природними ресурсами морів та океанів, розширення зовнішньоекономічного потенціалу, що формується на рівні підприємств, регіонів і країн [3]

К. Трунін визначає морегосподарський комплекс України як сукупність галузей економіки України, що беруть участь у переробленні ресурсів Чорного й Азовського морів, Світового океану, та галузей, які забезпечують їх діяльність [4, с. 122].

М. Волосюк та Л. Вдовиченко наголошують, що «морегосподарський комплекс - це складна, багатокомпонентна керована економічна система, у межах якої виокремлюються дві підсистеми: «морська» економіка, що безпосередньо пов'язана $з$ морською діяльністю, уключаючи їі морські та прибережні види (морський транспорт, рибальство, добуток морських мінеральних ресурсів, морські круїзи та суднобудування); «прибережна» економіка, яка пов'язана з розвитком прибережних територій, що забезпечують доступ до отримання вигід від морської діяльності (зокрема, неморські галузі за рахунок взаємодії з різними видами морської діяльності)». Тобто морегосподарський комплекс визначається як інтегральне явище, оскільки він об'єднує державну та регіональну політику, підтримку малого бізнесу, залучення іноземних та внутрішніх інвестицій, інноваційну політику, науково-технічну, освітню тощо [5, с. 44].

Отже, морегосподарський комплекс є міжгалузевим складним, багатопрофільним, цілісним акватериторіальним, функціонально-виробничим й економіко-екологічним формуванням, що включає в себе такі компоненти: наукову сферу: інститути і лабораторії морського профілю, наукові станції, особливо охоронювані морські і прибережно-морські акваторії; рекреаційний видобуток морських ресурсів: туристичні бази, яхтклуби, центри дайвінгу; машинобудування: суднобудування, судноремонт, виробництво обладнання, суднових установок та їх вузлів, служби контролю, моніторингу, підготовка кадрів для морського машинобудування; морський транспорт: судна морського транспорту (вантажні і пасажирські), порти, нафтотермінали, газові термінали, служби контролю, моніторингу, логістичні центри, підготовка кадрів для морського транспорту; рибне господарство: рибодобування, рибоперероблення, марикультура, наукове забезпечення рибної галузі, підготовка кадрів (ЗВО, коледжі, училища), служби контролю та моніторингу; видобуток морських ресурсів: нафтогазових, залізомарганцевих конкрецій, будівельної сировини, служба контролю та моніторингу. 

(рис. 1.).

Це дозволяє класифікувати нам основні напрямки діяльності морегосподарського комплексу

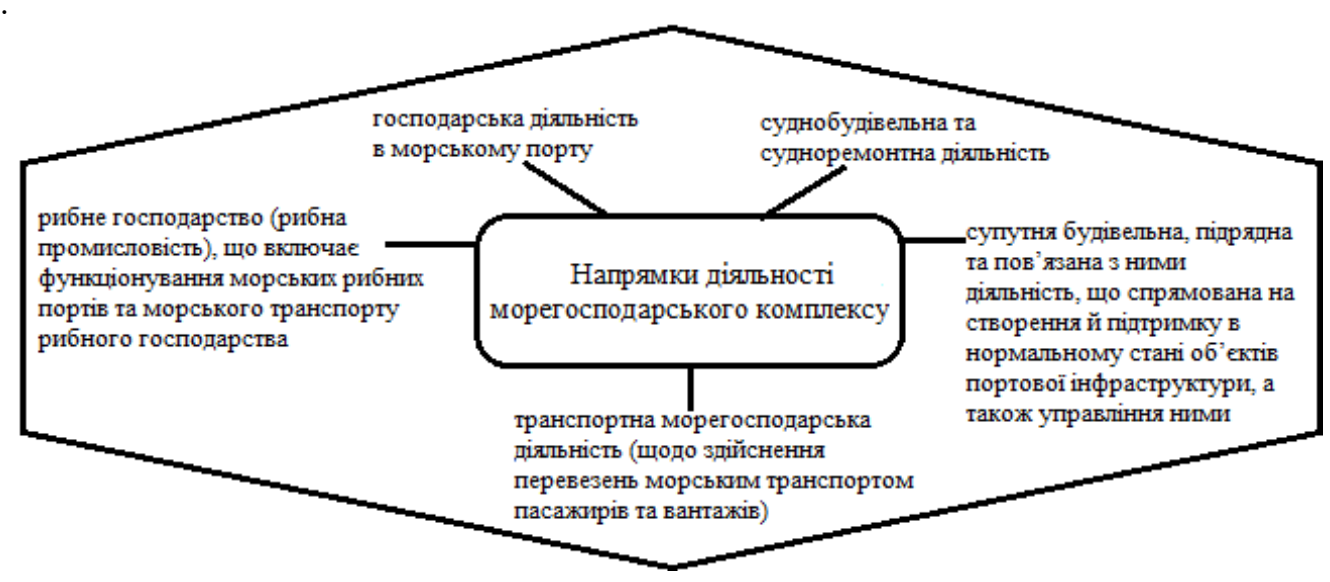

Рис.1 Основні напрямки діяльності морегосподарського комплексу

Джерело: складено авторами за класифікацією В. Котлубая [6, с. 55],

Слід звернути увагу, що від самого початку відновлення 1991 року незалежності Україною формування морегосподарського комплексу відбувалося стихійним шляхом, що призвело до виникнення значних диспропорцій у розвитку окремих галузей та сегментів. Ідентифікація характеру та природи означених диспропорцій заснована на гіпотезі щодо розбіжностей у стратегічних цілях та операційних завданнях між окремими галузями та підприємствами в умовах використання спільних ресурсів та функціонування в межах визначених приморських територій [7, с. 44]. Сьогоденні реалії функціонування морегосподарського комплексу України свідчать про його невідповідність зростаючим потребам у відповідних видах діяльності морської галузі, вимогам європейських стандартів якості надання транспортних послуг. Л. Гришина, П. Карась та Л. Філіпішина, досліджуючи тенденції функціонування вітчизняної сфери морської діяльності, відзначають, що під тиском загальних несприятливих економічних умов, Україна втрачає лідерство в обслуговуванні експортно-імпортних морських вантажопотоків, а внаслідок високого рівня зношеності виробничого потенціалу морського транспорту прискорюється зниження конкурентоспроможності підприємств морського транспорту [8, с. 133].

Крім того, серед негативних тенденцій сучасного морегосподарського комплексу відмічається низький рівень інноваційної діяльності, обмеженість здійснення науково-дослідних та дослідноконструкторських робіт у розбудові морської галузі, посилення проблем у соціальній сфері діяльності підприємств морської індустрії (забезпечення робочими місцями, достатнього рівня оплати праці, дієва система стимулювання працівників морської галузі, тощо) [9, с. 223].

Одним із напрямків координації та державного регулювання розвитку морегосподарського комплексу може стати кластерний підхід до організації морегосподарської діяльності. На нашу думку він має низку переваг перед традиційною галузевої формою, оскільки розвиваючи стратегічні ініціативи в межах галузевого підходу, уразливою ланкою стає узгодження галузевих стратегій у певних прибережних зонах, міжгалузеві диспропорції. Усуненню цих прогалин сприяють кластери неформальні об'єднання великого бізнесу з безліччю малих і середніх підприємств, інжинірингових, проєктних i конструкторських компаній, навчальних закладів, промислових асоціацій, фірм, що представляють ринкову і виробничу інфраструктуру та взаємодіють один з одним для випуску певного типу продуктів і виконання послуг у межах єдиного ланцюжка створення вартості.

I тут слід звернути увагу на те, що в морегосподарській діяльності кластерний підхід відіграє особливу роль через об'єктивно високий взаємозв'язок галузей, що становлять морський кластер, обмеженість прибережної зони (у просторовому аспекті), особливості взаємодій морського середовищаекономіки, значущістю для розвитку країни. Створення морського кластера дозволить здійснити координацію планів розвитку різних галузей, пов'язаних як технологічно, так і просторово у використанні єдиної прибережної зони. Рекомендації з розвитку морського кластера залежать від стадії життєвого циклу кластерів, а також зрілості секторів, що входять до них, які є потенційними або реальними учасниками кластеру. Отже, стає зрозумілим, що державна політика в цьому разі має бути спрямованою на стимулювання розвитку кластерів з урахуванням ситуації в конкретному регіоні або країні, використовуючи різні інструменти реалізації кластерної політики. Інший напрямок у політиці формування й розвитку морського кластера, пов'язаний з підтримкою сформованих секторів морського кластера (морський транспорт, суднобудування, рибне господарство та рибальство). Третій загальний напрямок, рекомендований для розвитку морського кластера, ми вбачаємо в активізації секторів, що мають високий потенціал для участі в морському кластері (морської туризм і рекреація, морська 
інженерія, охорона навколишнього середовища тощо). Однак, слід звернути увагу, що при розробленні конкретної програми кластерного розвитку слід концентруватися одночасно на поєднанні двох напрямків: розширення і поглиблення вітчизняного ринку і залучення іноземних інвесторів.

Отже, гарантією успішного функціонування морегосподарського комплексу в довгостроковій перспективі $є$ його здатність адаптуватися відповідно до мінливих ринкових умов. Цього можна досягти шляхом запровадження передових інноваційних технологій, модернізації основних фондів, технічного переоснащення та формування нової комплексної моделі управління.

Ми поділяємо думку О. Гайду, який, досліджуючи архітектоніку морегосподарського комплексу, згрупував чинники розвитку морегосподарського комплексу відповідно до їх цільового впливу на забезпечення сталості розвитку об’єкта, а саме:

а) чинники, що визначають економічну самостійність і розвиток: морська торгівля, імпорт i експорт, морський пасажирський флот, рекреаційна діяльність, вуглеводневі і мінеральні корисні копалини, видобуті на морському шельфі, промислове рибництво та рибальство, морські біоресурси;

б) чинники, що визначають економічну i військово-політичну безпеку: захист акваторії, узбережжя, морських споруд і комунікацій на стратегічно важливих напрямках, збереження і збільшення військової, дипломатичної та економічної присутності в регіонах, що входять до кола національних інтересів України, виконання миротворчих місій за мандатом $\mathrm{OOH}$, збереження впливу за кордоном, що забезпечує безпеку інвестицій;

в) чинники, що визначають рівень розвитку соціальної сфери: стан розвитку соціальної інфраструктури; доступність охорони здоров'я, освіти, культури; можливість вирішення житлової проблеми; змістовне проведення вільного часу; прожитковий рівень пенсій, стипендій; чітке функціонування комунальної сфери [10].

Однак ефективне функціонування морегосподарського комплексу України можливе лише за підтримки вітчизняної морської галузі державою, формування сприятливих умов для залучення інвестицій у розвиток морської індустрії, надання податкових та інших пільг суднобудівним підприємствам тощо.

Виходячи із вищесказаного, основними кроками вдосконалення державного регулювання розвитку морегосподарського комплексу України мають стати: забезпечення дієвих нормативноправових, фінансових, організаційно-економічних механізмів розвитку морської галузі; створення умов для ринкового саморегулювання морської галузі, ліквідація або перепрофілювання частини підприємств суднобудування і судноремонту, що не можуть витримати ринкової конкуренції; залучення інвестицій для розвитку морських портів та об'єктів їх інфраструктури, передача підприємств портової галузі та частини об'єктів портової інфраструктури, зокрема в концесію [11]; підвищення конкурентоспроможності водного транспорту на внутрішньому і зовнішньому ринку транспортних послуг; приведення стандартів безпеки роботи морських портів відповідно до міжнародних стандартів та вдосконалення системи логістики тощо [12].

3 метою прискорення інтеграції вітчизняного морегосподарського комплексу до європейської економічної системи, підвищення його конкурентоспроможності та здатності задовольняти потреби національної економіки та населення слід також здійснити техніко-технологічне оновлення суднобудівного виробництва, модернізацію наявної інфраструктури морських і річкових портів, упровадження мультимодальних транспортних технологій та інфраструктурних комплексів [8, с. 134].

\section{Висновки}

Отже, успішність функціонування та розвитку морегосподарського комплексу України потребує масштабних реформ та вдосконалення наявної морської політики 3 метою втілення сучасних та прогресивних методів, ефективність яких доведено світовою практикою. Задля дальшого підвищення ефективності функціонування морегосподарського комплексу необхідним $є$ розроблення стратегії його збалансованого розвитку та створення засад оптимальної реалізації завдань морської політики держави. Рушійною силою такого розвитку є синергія інтересів багатьох суб'єктів на основі використання інноваційних форм взаємовигідної співпраці з урахуванням світового досвіду ефективної інтеграційної діяльності як на національному, так i на наднаціональному рівнях. Реальна підтримка держави у вирішенні численних проблем морегосподарського комплексу $є$ запорукою отримання оптимальних результатів його розвитку. Своєю чергою, створення морського кластера дозволить здійснити координацію планів розвитку морегосподарського комплексу в недалекій перспективі.

\section{Список використаної літератури}

1. Про затвердження Морської доктрини України на період до 2035 р.: Постанова Кабінету Міністрів України від 7 жовтня 2009 р. № 1307. URL: http://zakon2.rada.gov.ua/laws/show/1307-2009$\% \mathrm{D} 0 \% \mathrm{BF}$

2. Горбаченко С., Каражія, Е., Структуризація морегосподарського комплексу України. Держава та регіони. Серія: Економіка та підприємнищтво, 2019 р., № 4 (109). С. 33-37. 
3. Розміщення продуктивних сил : підручник / [В. В. Ковалевський, О. Л. Михайлюк, В. Ф. Семенов та ін.] ; за ред. В. В. Ковалевського та ін. К. : Товариство «Знання»; КОО, 1998. 502 с.

4. Трунін К. С. Структурування морегосподарського комплексу України. Збірник наукових працьь Національного університету кораблебудування, 2014. № 1. С. 120-125.

5. Волосюк М. В., Вдовиченко Л. Ю. Морегосподарський комплекс: проблеми розвитку та регулювання : монографія. Київ : Центр учбової літератури, 2018. 152 с.

6. Котлубай В. О. та ін. Державна підтримка розвитку морегосподарського комплексу України (організаційні та правові аспекти) : монографія / за ред. О. М. Кібік, О. П. Подцерковного. Херсон : ФОП Грінь Д.С., 2014. 442 с.

7. Горбаченко, С. А., Горбаченко, С. А. Морегосподарський комплекс України: просторові аспекти розвитку. Приазовський економічний вісник, 2019. Випуск 4 (15). С. 43-47.

8. Гришина, Л. О., Карась, П. М., Філіпішина, Л. М. Тенденції, проблеми та перспективи розвитку морегосподарського комплексу України в умовах євроінтеграції. Науковий вісник Ужгородського національного університету. Серія: Міжнародні економічні відносини та світове господарство. Випуск 24. Частина 1, 2019. С.131-135.

9. Гуренко А. В., Щеникова Е. В., Свсік М. С. Дослідження сучасного потенціалу морегосподарського комплексу України. Вісник Приазовського технічного університету, 2017. Вип. 33. C. 218-224.

10. Гайду О.В. Державні пріоритети розвитку морегосподарського комплексу України: науковий огляд наявних і прихованих можливостей. Вісник Національного університету ичивільного захисту України : зб. наук. пр. Серія : Державне управління. Х. : Вид-во НУЦЗУ, 2016. Вип. 1 (4). С. 50-60.

11. Лопушинський І. П., Смельянов В. М. Концесія в портовій галузі України як форма державно-приватного партнерства. Публічне управління та регіональний розвиток, 2021. № 11. С. 232250 .

12. Філіппова В. Д., Шепетовський О. С. Базові моделі державного управління розвитком морських портів. Теорія та практика державного управління і місиевого самоврядування: електрон. наук. фах. вид. Херсон, 2019. №2. URL:: http://el-zbirn-du.at.ua/2019_2/23.pdf

\section{References}

1. Pro zatverdzhennia Morskoi doktryny Ukrainy na period do 2035 r. : Postanova Kabinetu Ministriv Ukrainy vid 7 zhovtnia 2009 r. no. 1307. URL: http://zakon2.rada.gov.ua/laws/show/1307-2009- \%D0\%BF

2. Horbachenko, S., Karazhiia, E. (2019) Strukturyzatsiia morehospodarskoho kompleksu Ukrainy. Derzhava ta rehiony. Seriia: Ekonomika ta pidpryiemnytstvo, 2019 r., no. 4 (109). pp.33-37.

3. Rozmishchennia produktyvnykh syl : pidruchnyk / [V. V. Kovalevskyi, O. L. Mykhailiuk, V. F. Semenov ta in.] ; za red. V. V. Kovalevskoho ta in. (1998) K. : Tovarystvo «Znannia»; KOO. 502 p.

4. Trunin K.S. (2014) Strukturuvannia morehospodarskoho kompleksu Ukrainy. Zbirnyk naukovykh prats Natsionalnoho universytetu korablebuduvannia. No. 1. pp. 120-125.

5. Volosiuk M.V., Vdovychenko L.Yu. (2018) Morehospodarskyi kompleks: problemy rozvytku ta rehuliuvannia : monohrafiia. Kyiv : Tsentr uchbovoi literatury, 2018. 152 p.

6. Kotlubai V.O. ta in. (2014) Derzhavna pidtrymka rozvytku morehospodarskoho kompleksu Ukrainy (orhanizatsiini ta pravovi aspekty) : monohrafiia / za red. O.M. Kibik, O.P. Podtserkovnoho. Kherson : FOP Hrin D.S. $442 \mathrm{~s}$.

7. Horbachenko, S. A., Horbachenko, S. A. (2019) Morehospodarskyi kompleks Ukrainy: prostorovi aspekty rozvytku. Pryazovskyi ekonomichnyi visnyk. Vol. 4(15). pp.43-47.

8. Hryshyna, L. O., Karas, P. M., Filipishyna, L. M. (2019) Tendentsii, problemy ta perspektyvy rozvytku morehospodarskoho kompleksu Ukrainy v umovakh yevrointehratsii. Naukovyi visnyk Uzhhorodskoho natsionalnoho universytetu. Seriia: Mizhnarodni ekonomichni vidnosyny ta svitove hospodarstvo. Vol.24. no.1. pp.131-135

9. Hurenko A.V., Shchenykova E.V., Yevsik M. S. (2017) Doslidzhennia suchasnoho potentsialu morehospodarskoho kompleksu Ukrainy. Visnyk Pryazovskoho tekhnichnoho universytetu. Vol. 33. pp. 218-224.

10. Haidu O.V. (2016) Derzhavni priorytety rozvytku morehospodarskoho kompleksu Ukrainy: naukovyi ohliad naiavnykh i prykhovanykh mozhlyvostei. Visnyk Natsionalnoho universytetu tsyvilnoho zakhystu Ukrainy : zb. nauk. pr. Seriia : Derzhavne upravlinnia. Kh. : Vyd-vo NUTsZU. Vol. 1 (4). pp. 50-60.

11. Lopushynskyi I.P., Yemelianov V.M. (2021) Kontsesiia v portovii haluzi Ukrainy yak forma derzhavno-pryvatnoho partnerstva. Publichne upravlinnia ta rehionalnyi rozvytok. No. 11. pp. 232-250.

12. Filippova V. D., Shepetovskyi O. S. (2019) Bazovi modeli derzhavnoho upravlinnia rozvytkom morskykh portiv. Teoriia ta praktyka derzhavnoho upravlinnia i mistsevoho samovriaduvannia: elektron. nauk. fakh. vyd. Kherson. No.2. URL:: http://el-zbirn-du.at.ua/2019 2/23.pdf 